IRSTI 06.73.15

\author{
Sagiyeva R.K. ${ }^{1}$, Kuanova L.A. ${ }^{2}$ \\ ${ }^{1}$ doctor of economics, acting professor, e-mail: rimmasagiyeva@gmail.com \\ ${ }^{2}$ doctoral student, e-mail: laura_kuanova@mail.ru \\ 1,2al-Farabi Kazakh National University, Kazakhstan, Almaty
}

\title{
ISLAMIC FINANCE IN KAZAKHSTAN: ADAPTATION OF FOREIGN EXPERIENCE
}

The relevance of the title studied in the article is due to the specifics of Islamic Finance, which demonstrate their advantages and find distribution throughout the world, both in the countries of Muslim society and in developed European countries. As Islamic Finance in Kazakhstan has not been developed properly since 2009, the authors set a goal to study the experience and mechanism of better adaptation and integration of Islamic Finance in the financial sector of the country. Based on the analysis of international experience of application of Islamic financial instruments developed and proposed recommendations for enhancing their implementation and increase the impact on the real sector of the economy of the Republic of Kazakhstan.

The results of the study showed that the problem of insufficient spread of Islamic banking and finance is using a more conservative model of development Islamic finance and the presence of some restrictive barriers of both prudential and social nature.

Research results. The results of the study can be used for the successful spread of Islamic Finance in Kazakhstan, as well as to promote economic cooperation with the countries of the Islamic world.

Application area. The results of the study can be used and applied to the successful experience of the implementation and development of Islamic Finance in Kazakhstan, and also with the economic cooperation of the countries of the Islamic world.

Key words: Islamic finance, Islamic bank, non-muslim countries, international experience, Islamic windows

$$
\begin{aligned}
& \text { Сағиева Р.Қ. }{ }^{1} \text {, Қуанова А.А. }{ }^{2} \\
& { }^{1} \text { э.ғ.А., профессор м.а., e-mail: rimmasagiyeva@gmail.com } \\
& { }^{2} \triangle \text { ОКторант, e-mail: laura kuanova@mail.ru } \\
& \text { 1,2әл-Фараби атындағы Қазақ ұлттық, университеті, Қазақстан, Алматы қ. }
\end{aligned}
$$

\section{Қазақстандағы исламдық қаржы: шетелдік тәжірибені бейімдеу}

Мақалада зерттелген тақырыптың өзектілігі мұсылман елдерінде де, дамыған еуропалық елдерде де артықшылықтарын көрсетіп, кең таралған Ислам қаржысының ерекшелігіне негізделеді. Қазақстандағы Исламдық қаржыландыру 2009 жылдан бастап тиісті дамуын таппағандықтан, авторлар елдің қаржы секторына Ислам қаржысының ең жақсы бейімделуі мен ықпалдасуының тәжірибесі мен тетігін зерттеу мақсатын алға қойды. Ислам қаржы құра^дарын пайдаланудың әлемдік тәжірибесін та^дау негізінде, оларды қолдануды жандандыру және Қазақстан Республикасы экономикасының нақты секторына әсерін арттыру жөнінде ұсынымдар әзірленді.

Зерттеу нәтижелері Ислам банкингі мен қаржыландырудың жеткіліксіз таралу мәселесі неғұрлым консервативті даму моделін пайдалану және пруденциалдық, сондай-ақ, әлеуметтік сипаттағы кейбір шектеу кедергілері болып табылатынын көрсетті.

Қолдану саласы. Зерттеу нәтижелері Қазақстандағы Ислам қаржысын кең тарату үшін пайдаланылуы, сондай-ақ ислам әлемі елдерімен экономикалық ынтымақтастықты кеңейтуге ықпал етуі мүмкін.

Түйін сөздер: исламдық қаржы, исламдық банк, мұсылман емес елдер, халықаралық тәжірибе, исламдық, терезелер. 


\author{
Сагиева Р.К. ${ }^{1}$, Куанова А.А. ${ }^{2}$ \\ ${ }^{1}$ А.э.н., и.о. профессора, e-mail: rimmasagiyeva@gmail.com \\ ${ }^{2}$ Аокторант, e-mail: laura kuanova@mail.ru \\ 1,2Казахский национальный университет им. аль-Фараби, Казахстан, г. А^маты \\ Исламские фринансы в Казахстане: адаптация зарубежного опыта
}

\begin{abstract}
Актуальность исследованной в статье темы обусловлена спецификой исламских финансов, которые демонстрируют свои преимущества и находят распростронение во всем мире, как в странах мусульманского общества, так и в развитых европейских странах. Поскольку исламское финансирование в Казахстане с 2009 года не нашло Аолжного развития, авторами поставлена цель изучения опыта и механизма кучшей адаптации и интеграции исламских финансов в финансовый сектор страны. На основе анализа мирового опыта использования исламских финансовых инструментов разработаны и предложены рекомендации по активизации их применения и увеличения влияния на реальный сектор экономики Республики Казахстан.

Результаты исследования показали, что проблема недостаточного распространения исламского банкинга и финансирования заключается в использовании более консервативной модели развития и наличием некоторых ограничительных барьеров как пруденциального, так и социального характера.

Область применения. Результаты исследования могут быть использованы Аля успешного распространения исламских финансов в Казахстане, а также способствовать расширению экономического сотрудничества со странами исламского мира.
\end{abstract}

Ключевые слова: исламские финансы, исламские банки, немусльманские страны, международный опыт, исламские окна, сукук.

\section{Introduction}

Islamic finance in recent years has attracted the attention of the traditional financial markets of nonMuslim countries. By some estimates, more than 300 financial institutions and 250 borrowing funds in more than 75 countries are engaged in Islamic finance, 45 of these countries use Islamic finance regulation system (S\&P, 2018; Thomson Reuters, 2018).

It should be noted that Islamic Finance is not limited to Islamic countries and is distributed wherever there is a large Muslim community.

The difference between Islamic financing and the traditional one is that the Islamic economic system is a system based on rules and the principles of preserving property rights and the inviolability of contracts and has no speculative component

Islamic finance and banking is a rapidly growing direction of the financial sector in the world. According to Global Islamic finance report of 2018, the annual turnover of the Islamic finance market is estimated at 2.431 trillion US dollars, which is $1 \%$ of all world assets, and average growth rate of World Islamic finance is $11,39 \%$ between $2009-2017$. The global Islamic financial services industry grew by 138 billion trillion US dollars from the end of 2016 to 2017 (Global Islamic Finance Report, 2018).

The fact that the global financial crisis has affected Islamic banks to a lesser extent due to the specifics of their activities, served as a definite impulse to the close attention of traditional financial markets to Islamic finance.

Nowadays, the geography of the spread of Islamic Finance and banking covers 75 countries and distributed in Gulf Cooperation Council and another non-GCC, Middle East and North Africa. Also, Islamic banks are developed in South Asia, in the East Asia and the Pacific region in Sub-Saharan Africa and in Europe (CIBAFI, 2017).

The trend of the widespread of Islamic finance demonstrates existence of specific characteristics, which not full studied by researches to the extend, that can be applied in Kazakhstan.

\section{Materials and methods}

The article uses the methods of system and descriptive analysis, scientific abstraction, system approach. A brief analysis of research investigating this issue is given. System analysis is a scientific method of cognition, which is a sequence of actions to establish structural relationships between variables or constant elements of the system under study. Descriptive method - a type of scientific method, which is a system of procedures for the collection, primary analysis and presentation of data and their characteristics. The article is preceded by an in-depth description (actually scientific) study by supplying samples and material for the deployment of further scientific procedures and methods regarding Islamic finance. The method 
of scientific abstraction - this is the method of economic theory, which allows to exclude from the consideration of individual non-essential relationships between the subjects of the economy and to focus on the consideration of several subjects. System approach in Economics is a methodological direction of scientific research, which consists in a comprehensive study of the economy as a whole from the standpoint of system analysis and synthesis. There has been used comprehensive analysis of experience of Islamic finance developed countries and studied on all sides of the economic aspects, by comparing. For comparative analysis, there have been used different countries from different regions and were identified features of the development of Islamic finance system.

\section{Literature review}

The article studies and summarizes the research of international organizations in the field of Islamic Finance and Islamic law. In addition, in article are studied the works of economists-scientists in Islamic finance, who researched features of the development and promotion of Islamic finance and banking in the World economy and by the regions and countries separately.

The article examines the works of Mohd Daud Bakar on the development and results of Islamic finance in Malaysia, which is the leading country in terms of Islamic security market assets in the world and temp of development of Islamic finance.

Nasim Shah Shirazi research covers such regions as Pakistan, Egypt and even the CIS countries the Republic of Kyrgyzstan and Tajikistan (Shirazi, 2014).

There also had been analyzed the studies of Baljeet Kaur Grewal, established on research of development of Islamic banking in Europe and United States of America (Grewal, ECB, 2013:2232).

This article studies the works of economists and scientists, however focus is based more on the financial statements of international financial organizations, such as AAOIFI (Accounting and Auditing Organisation for Islamic Financial Institutions), CIBAFI (General Councul for Islamic banks and financial instruments), IFSB (Islamic Financial Services Board) and others. By using data and studying the most effective development model, recommendations were developed that are adaptable in the Kazakhstan financial market.

In addition, among other scientific papers, carefully studied all the laws that have been amended and supplemented on the organization and activities of Islamic banks and the organization of Islamic Finance in the Republic of Kazakhstan.

Ergec, E., \& Arslan, B. (2013). Impacts of interest rates on Islamic and conventional banks: The case of Turkey. Applied Economics,45(17), 2381-2388.

Gheeraert, L., \& Weill, L. (2015). Does Islamic banking development favour macroeconomic efficiency? Evidence on the Islamic finance-growth nexus. Economic Modelling,47,32-39.

Hasan, M., \& Dridi, J. (2010). The effects of the global crisis on Islamic and conventional banks: A comparative study (IMF Working Paper \#WP/10/201). Retrieved from the IMF website (https://www.imf.org/external/pubs/ft/wp/2010/ wp10201.pdf).

Ibrahim, M. H. (2016). Business cycle and bank lending procyclicality in a dual banking system. Economic Model-ling,55, 127-134.

Ibrahim, M. H., \& Sukmana, R. Ergec, E., \& Arslan, B. (2013). Impacts of interest rates on Islamic and conventional banks: The case of Turkey. Applied Economics,45(17), 2381-2388.

Gheeraert, L., \& Weill, L. (2015). Does Islamic banking development favour macroeconomic efficiency? Evidence on the Islamic finance-growth nexus. Economic Modelling, 47,32-39.

Hasan, M., \& Dridi, J. (2010). The effects of the global crisis on Islamic and conventional banks: A comparative study (IMF Working Paper \#WP/10/201). Retrieved from the IMF website (https://www.imf.org/external/pubs/ft/wp/2010/ wp10201.pdf).

Ibrahim, M. H. (2016). Business cycle and bank lending procyclicality in a dual banking system. Economic Model-ling,55, 127-134.

Ibrahim, M. H., \& Sukmana, R. Ergec, E., \& Arslan, B. (2013). Impacts of interest rates on Islamic and conventional banks: The case of Turkey. Applied Economics,45(17), 2381-2388.

Gheeraert, L., \& Weill, L. (2015). Does Islamic banking development favour macroeconomic efficiency? Evidence on the Islamic finance-growth nexus. Economic Modelling,47,32-39.

Hasan, M., \& Dridi, J. (2010). The effects of the global crisis on Islamic and conventional banks: A comparative study (IMF Working Paper \#WP/10/201). Retrieved from the IMF website (https://www.imf.org/external/pubs/ft/wp/2010/ wp10201.pdf).

Ibrahim, M. H. (2016). Business cycle and bank lending procyclicality in a dual banking system. Economic Model-ling,55, 127-134. Ibrahim, M. H., \& Sukmana, R. 


\section{Results and discussion}

To analyze the development and potential of the Islamic banking system in Kazakhstan, it is necessary to review the development of this system in the world by the example of a number of foreign countries, both Muslim and non-Muslim. Drawing a parallel between the pace of development of Islamic finance in foreign countries and in our country, with the goal of adopting international experience for its using in Kazakhstan.

However, one of the serious problem arising in the analysis of the Islamic banking system is the lack of reliable statistical information about the entire sector in general. The joint work of the Islamic Research and Training Institute, Islamic Development Bank and the Islamic Financial Services Board summarizes some of the findings of various researchers of the Islamic financial system. (www.ifsb.org) The only official source of information on the Islamic banking system is the Council for Islamic Banks and Financial Institutions (CIBAFI). Thus, according to CIBAFI, the following chart was drawn up, illustrating the growth in the number of Islamic banks for the period from 1963 to 2018 .

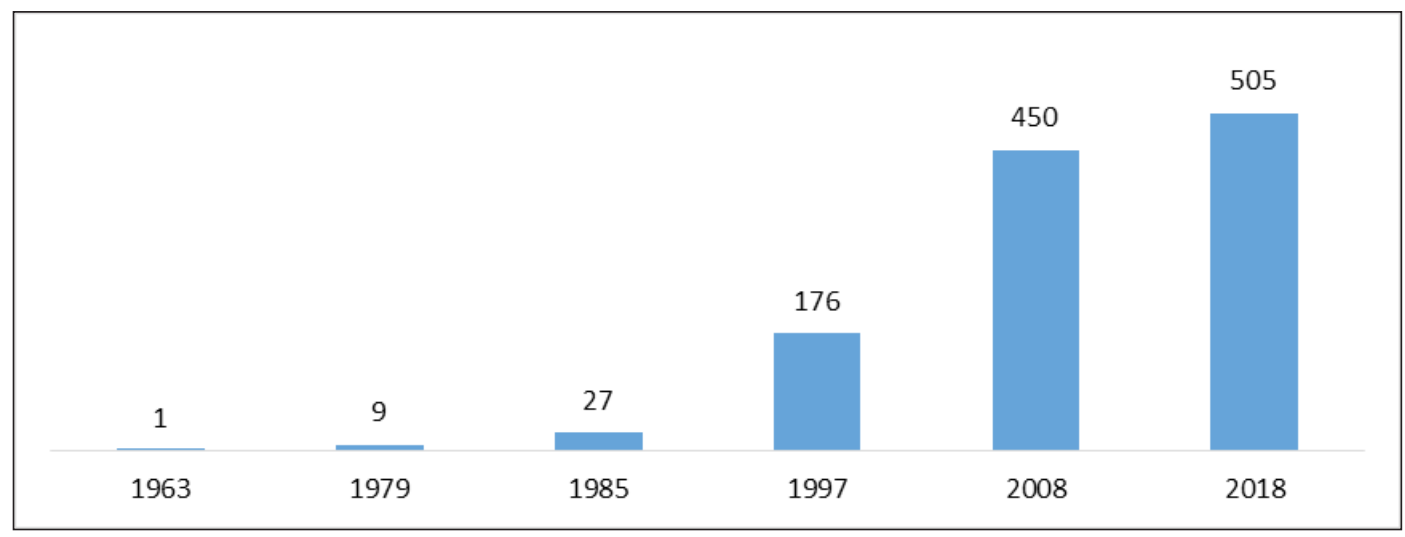

Figure 1 - The number of Islamic banks in the world Source: CIBAFI, 2018

As can been seen from diagram above, during the years of economic crisis there has been an increase in Islamic financial institutions by hundreds institutions, which indicates that the industry is being popularized despite the crisis period.

However, it is well known fact that Islamic finance service industry is not consists not only from banking system, but also from Sukuk (Islamic securities) sector, Islamic founds and takaful (Islamic insurance). From the following figure it could be mentioned that Islamic banking (76\%) is the biggest sector of Sharia-compliant finance industry.

As can been seen from the data bellow, Sukuk market accounts for $20 \%$ of the Islamic finance industry, for the comparative analysis in the article it has been decided took into account the sukuk market.

The global sukuk market totals around 400 billion US dollars according to a range of estimates, and with 65 products worth of total of 48 billion US dollars listed on the London Stock Exchange, the UK is a major centre for Islamic bonds (www. telegraph.co.uk, 2017).
The geography of the distribution of Islamic finance instruments in the world is not limited to Islamic countries; the products of the Islamic finance system are also common in Europe, the US, Southeast Asia and the Middle East.

Leader of amount of Islamic banking assets is Iran by $34.4 \%$, and then follows Saudi Arabia, 20.4\%. In Malaysia, the share of Islamic banking assets is $9.1 \%$ of all banking assets, in the UK the share of Islamic banks is $0.18 \%$, in Turkey $-2.6 \%$, in Indonesia - 1.8\%. (IFSB, 2018:30-34) It can be illustrated in the following way.

From the given data on figure 4, the following countries will be studied in article as leaders of the industry: Iran, Saudi Arabia, Malaysia, UAE and Qatar. It is well known fact, that Islamic banking has gained the most popularity among developed countries in the US, and in Britain, experience of these countries will be considered in the research. Furthermore, there will be studied countries of the independent states (CIS). 


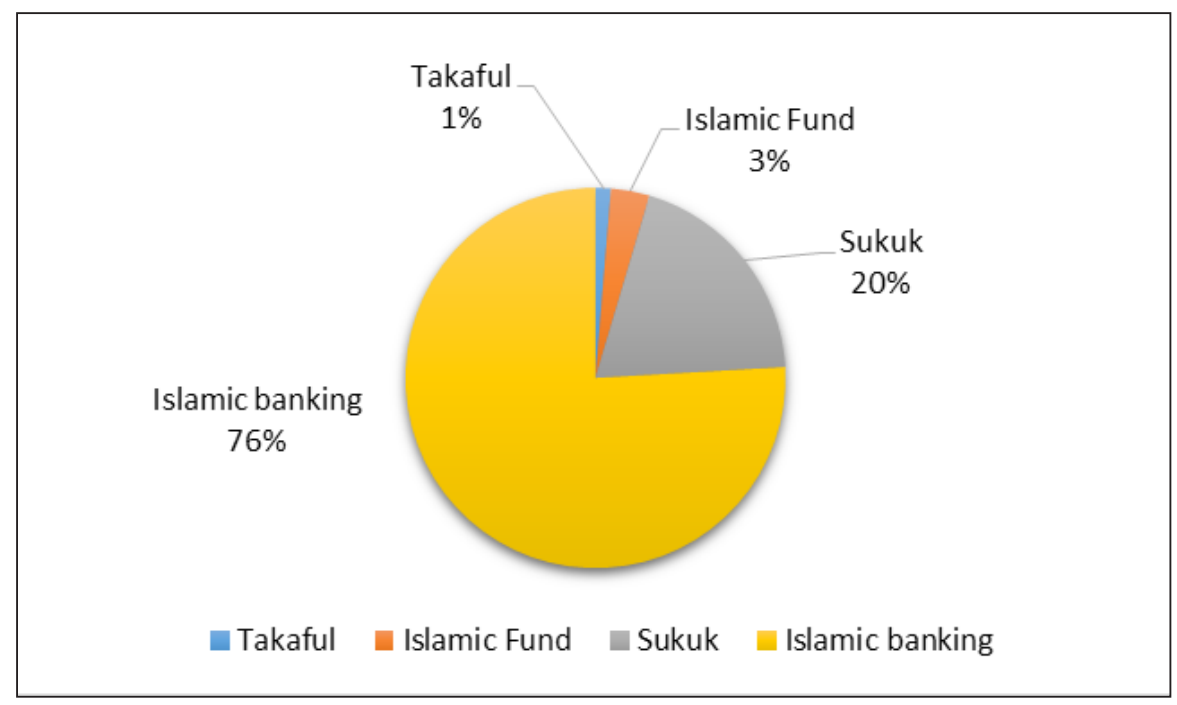

Figure 2 - Sectoral composition of the Global Islamic finance services Source: CIBAFI, 2017

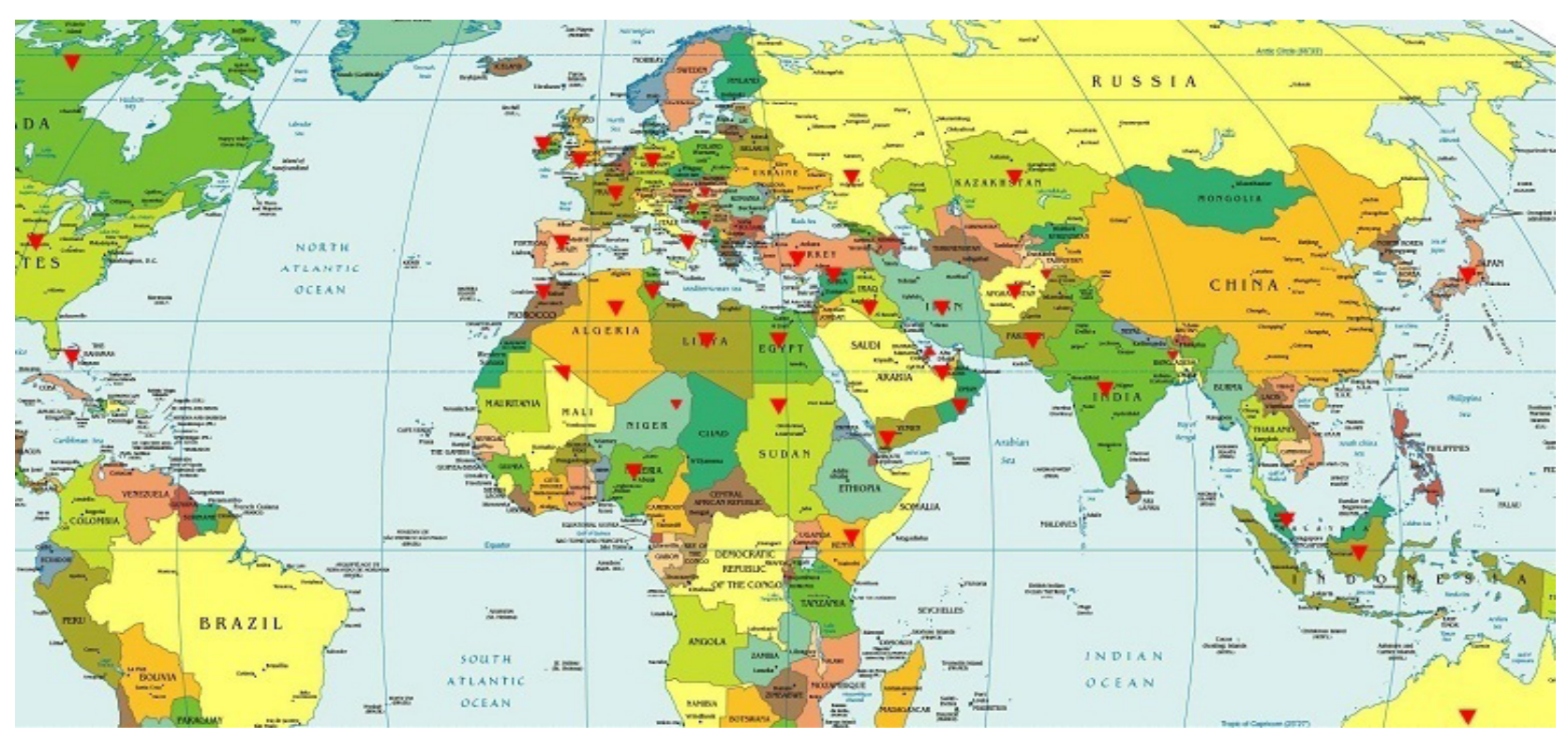

Figure 3 - Map of distribution of financial products based on Islamic principles Source: IFSB, 2017

In the 1970s - 1980s, large Islamic banks such as the Dubai Islamic Bank (UAE), the Faisal Islamic bank of Egypt, the Faisal Islamic Bank of Sudan first were established in Muslim countries. In addition, the largest Islamic banks of Muslim countries include Abu Dhabi Islamic Bank (UAE), Faisal Islamic Bank of Egypt (Egypt), Al Rajhi Banking \& Investment Corp (Saudi Arabia, there are branches in Malaysia), Shamil Bank of Bahrain (Bahrain).
It is well known fact that, the Gulf Cooperation Council countries are the largest region for Islamic finance assets, there are dual system of both local investment banks: First Islamic Investment Bank (Bahrain), The International Investment Bank (Kuwait), and international banks offering services consistent with Islam: HSBC, UBS (mainly in Bahrain and the UAE). Citibank has also been working with Islamic banking structures for a long time. 
Sagiyeva R.K., Kuanova L.A.

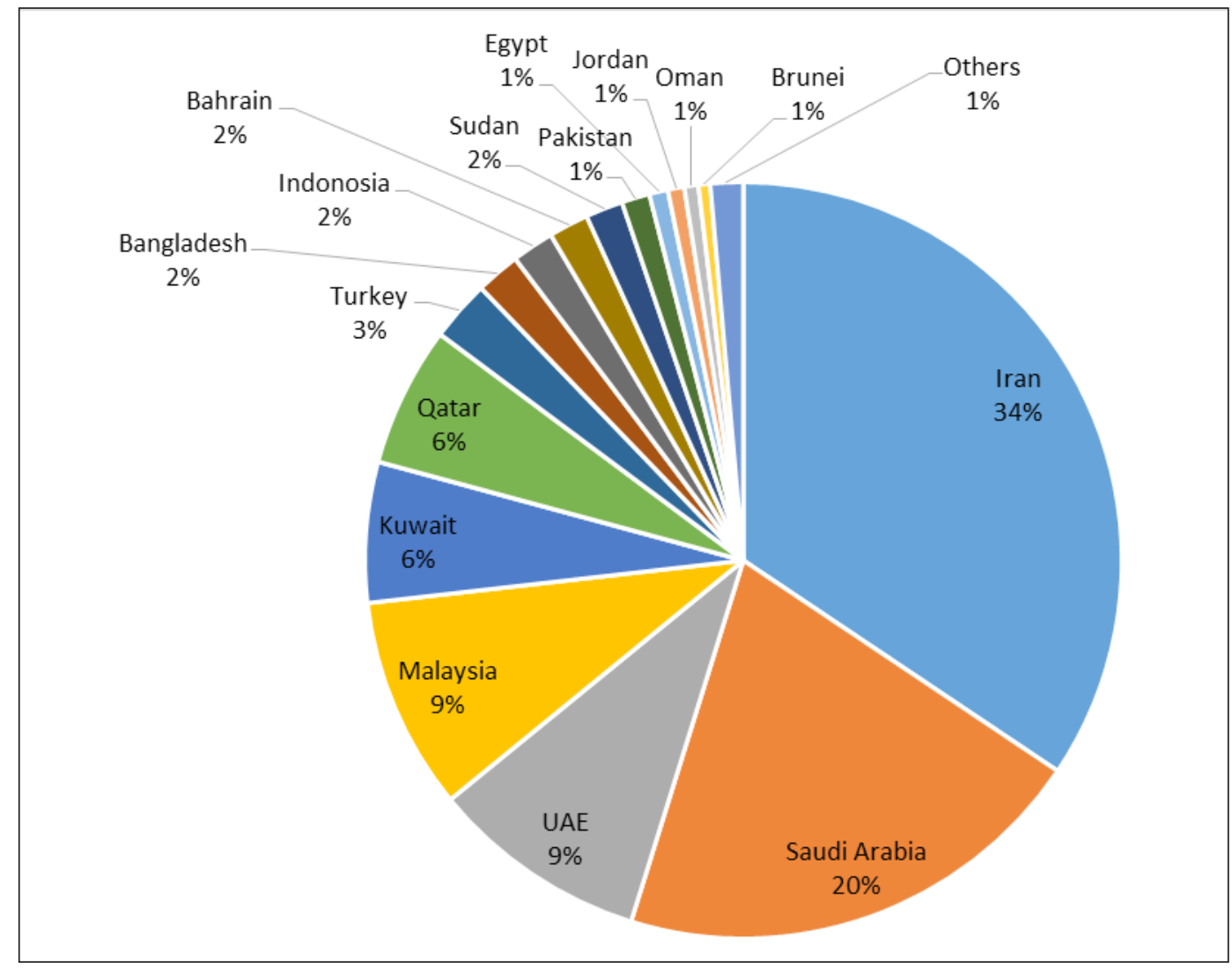

Figure 4 - Shares of Global Islamic Banking Assets Source: IFSB, 2018

There are number of researches and reports which are concluded that regionally, the Gulf Cooperation Council continues as the largest domicile for Islamic finance assets. In 2017, the region experienced a slight moderation in market share to $42 \%$ of the global Islamic Finance Services Industry (IFSB Secretariat Workings, 2018).

In the banking system of Malaysia, both ordinary and Islamic financial institutions operate. The first in 1963, a charitable foundation was founded that attracted Muslims' savings for pilgrimage. Further on the basis of this charitable foundation was created the Islamic investment fund Tabung Haji. However, the rapid development of Islamic banking in the country began in the 80 's, after the Bank Islam Islamia Berhad was founded in 1983.

Only ten years later, in 1993, a banking program based on an interest-free was introduced, according to which ordinary banks began to provide Islamic services. After that, several dozen new players appeared quickly enough, and the product line increased to 40 different types of services. A number of major innovations occurred in the nineties, such as the establishment of a market for Islamic interbank operations in 1994, the introduction of a form of reporting on operations under the Sharia of traditional banks in 1996, the formation of the Shariah Council as an authority interpreting Islamic norms in banking in 1997. In 1999, the country created the second fully Islamic bank - Bank Muamalat Malaysia Berhad.

Currently, there are 16 banks in Malaysia that provide exclusively Islamic financial services. In addition, 9 local banks and banks with foreign participation, such as HSBC, Oversea-Chinese and Standard Chartered, offer products on the principles of Sharia (www.bnm.gov). According to the World Bank's report from 23 February, 2017 Malaysia has 1,03 Islamic finance institution per very 10 thousand km (World bank, 2017).

The main market in the Islamic financial system of Malaysia is the securities market, accounting for two thirds of the world sukuk market.

The Islamic assets of Malaysian banks amounted to 65.6 billion dollars. According to the Central Bank of Malaysia, the increase in Islamic banking by banks in the assets of the country's banking system amounted to $18-20 \%$ annual (www.bnm. 
gov). At the same time, it must be remembered that the role of the primacy in the Islamic segment of the banking system of Malaysia belongs to traditional financial institutions participating in an interest-free banking program. This model of developing Islamic finance in the country has assisted to the increasing in the sector and has provided implementation of Islamic finance and business.

The different models of the development of Islamic financial institution will studied latter for clearance of comparative review of authors.

The United Kingdom has one of the most advanced Islamic financial markets in the western world and is quickly becoming a key destination for foreign Shariah-compliant institutions. London in particular is an important financial center, with major international firms and the Middle East's biggest traditional banks offering Islamic products in this city. Islamic financing activities started in the UK in the 1980s when the London Metal Exchange provided Islamic overnight deposit facilities based on the murabahah principle (Filipo and others, 2013:29-31).

In August 2004, the Islamic Bank of Britain, the first Islamic Bank in Europe, began operating in London. However, the prerequisites for the creation of a financial institution operating on the principles of Islam in the UK have arisen for a long time before. In particular, in the 1980s, the Islamic Bank Al-Baraka worked in the country, providing services to both Muslims and representatives of other religions. But due to the stricter requirements and standards of the Bank of England, in 1993 alBaraka Bank continued its activities as an Islamic investment company and stopped providing banking services. After 1993, Islamic financial services in the UK were provided by so-called Islamic «Windows» of such banks as HSBC, Citibank, but there was no independent Bank providing only Islamic banking services in the UK. Despite all difficulties in of requirements, there are five fully Shariah-compline banks in the UK, these days: Abu Dhabi Islamic Bank, Al Rayan Bank, Bank of London and The Middle East, Gatehouse Bank, QIB UK (Wayene, 2017: 5).

According to the report published in 2017 by the International Financial Service London (IFSL), the UK is the leading Islamic financial center in Western Europe and ranks ninth in the world in terms of the corresponding Sharia assets in the amount of 10.4 billion dollars, services in this area are provided by 23 banks (IFSL, 2017).

In general, Islamic banking in the CIS countries has not received much development, which is due to the historically prevailing preferences of economic agents and to a low degree of client awareness. However, in recent years, awareness of the Islamic financial system has increased, in terms of an alternative source of funding.

The main reason that hinders the development of Islamic banking in the CIS countries is the inconsistency of the principles of Islamic financing to legislation. Kazakhstan is the founder of the legislative and regulatory framework for the work of Islamic financial institutions among the CIS countries.

It is worth noting the experience of Kyrgyzstan, where work is being carried out to introduce Islamic banking based on one bank «EcoIslamicBank» (www.24.kz, 2017). According to official financial information to 31.12.2017 of EcoIslamicBank, assets of bank are 2,826 billion som, which is 40, $519 \mathrm{mln}$ US dollars (EcoIslamicBank, 2018).

There were at least three attempts to create Islamic banks in Russia, but they were unsuccessful. Thus, Islamic banks opened in 1992 in Kemerovo and in 1996 in Makhachkala ceased to exist. More successful was the attempt to organize the Islamic Badr Bank in 1997, but also in December 2006, the Bank of Russia revoked its banking license (Antropov, 2017: 63).

Thus, there have been shown that Islamic financial institutions are beginning to play an increasingly important role in the world financial system nowadays. At the same time traditional Islamic financial products can be adapted in such a way that they can be offered relatively easily by ordinary banks. In this, often the emergence of Islamic banks in traditional banking markets entails certain difficulties, related both to the adaptation of the banks themselves and to the legislative regulation of banking activities.

Kazakhstan has fundamental role in the development of Islamic banking at the legislative level, and in the development of Islamic finance in the territory of the CIS and Central Asia.

As it can been seen from table 1, there is no doubt that growth in Islamic banking and finance is closely linked with the oil prices. Over $80 \%$ (US\$1,877 billion) of the global Islamic financial assets are concentrated in the 10 countries with oil dependence (Dubai Islamic Bank, 2017: 11). These countries' public finances are likely to be most affected by the decline in the oil prices. Governments in these countries have often used Islamic finance to diversify their funding profiles but also to demonstrate their support for the growth and development of what is seen as an indigenous industry with many local stakeholders. 
Sagiyeva R.K., Kuanova L.A.

Table 1 - Islamic financial assets in selected countries, billion US dollar

\begin{tabular}{|c|c|c|c|c|c|c|c|c|c|c|c|}
\hline Country & 2007 & 2008 & 2009 & 2010 & 2011 & 2012 & 2013 & 2014 & 2015 & 2016 & $\%$ \\
\hline Iran & 235 & 293 & 369 & 406 & 413 & 416 & 480 & 530 & 544 & 560 & 12,7 \\
\hline Saudi Arabia & 92 & 128 & 161 & 205 & 215 & 270 & 339 & 371 & 401 & 333 & 20,95 \\
\hline Malaysia & 67 & 87 & 109 & 120 & 131 & 155 & 200 & 249 & 254 & 335 & 20,89 \\
\hline UAE & 48 & 84 & 106 & 116 & 118 & 120 & 123 & 144 & 157 & 197 & 18,57 \\
\hline Qatar & 21 & 28 & 35 & 38 & 47 & 68 & 70 & 111 & 122 & 130 & 28,11 \\
\hline Turkey & 16 & 18 & 22 & 41 & 43 & 55 & 61 & 43 & 80 & 81 & 24,41 \\
\hline UK & 18 & 19 & 24 & 27 & 33 & 37 & 40 & 43 & 55 & 61 & 13,47 \\
\hline Kazakhstan & 0 & 0 & 0 & 0,043 & 0,074 & 0,08 & 0,113 & 0,078 & 0,148 & 0,61 & 15,3 \\
\hline
\end{tabular}

Islamic financial services are offered via different structures, depending on whether or not the institution also offers conventional financial services. Institutions that provide conventional, as well as Islamic financial services, have three main organisational structures available to them. Although in some countries, such as Iran and Sudan, the complete financial system is Shariah compliant, in the majority of countries, Shariah-compliant and conventional banks exist side by side. The amount of full-flegded Islamic bank system is $76.53 \%$ of Global
Islamic banking operation (CIBAFI, 2018:23). In workbook of the Chartered Institute for Securities \& Investment's Islamic Finance Qualification is considered that when conventional banks offer Islamic financial services, this is typically done using one of the following organisational models: the Windows Model (16.33\% from Global Islamic banking operation), Branches, Subsidiaries (7.14\%) (CISI, 2018:28-29). This information will be useful for further study of implementation of Islamic finance in selected countries.

Table 2 - Comparative analysis of the features of implementation and development of Islamic finance by country

\begin{tabular}{|c|c|c|c|c|c|c|}
\hline \multirow[t]{2}{*}{ Country } & \multirow[t]{2}{*}{ IF development period } & \multirow{2}{*}{$\begin{array}{l}\text { Islamic } \\
\text { Banks }\end{array}$} & \multicolumn{2}{|c|}{$\begin{array}{c}\text { Sukuk market } \% \text { from } \\
\text { world issuance ( } \$ 342 \mathrm{bln} .)\end{array}$} & \multirow[t]{2}{*}{ Model } & \multirow[t]{2}{*}{ Feature } \\
\hline & & & Corp. & Suv. & & \\
\hline Iran & $\begin{array}{c}1979 \\
\begin{array}{c}\text { Nationalization of all } \\
\text { banks }\end{array}\end{array}$ & 40 & & 1.1 & Islamic & Total Shariah Low \\
\hline Saudi Arabia & $\begin{array}{c}1978 \\
\text { Al Rajhi Investment Co }\end{array}$ & 13 & 3.1 & 38.81 & Islamic & Total Shariah Low \\
\hline Malaysia & $\begin{array}{c}1983 \\
\text { Bank Islam Islamia Berhad }\end{array}$ & 13 & 60.6 & 32.89 & Islamic windows & $\begin{array}{c}\text { Developed Sukuk } \\
\text { market }\end{array}$ \\
\hline UAE & $\begin{array}{c}1975 \\
\text { Dubai Islamic Bank }\end{array}$ & 18 & 12.9 & 2.21 & $\begin{array}{l}\text { Conventional and } \\
\text { Islamic, Islamic } \\
\text { windows }\end{array}$ & Loyal \\
\hline Qatar & $\begin{array}{c}1982 \\
\text { Qatar Islamic Bank }\end{array}$ & 4 & 5.2 & 5.49 & $\begin{array}{l}\text { Conventional and } \\
\text { Islamic }\end{array}$ & $\begin{array}{l}\text { Loyal and } \\
\text { technical }\end{array}$ \\
\hline Turkey & 2005 & 5 & 7.2 & 3.15 & Islamic windows & Fast growing \\
\hline UK & $\begin{array}{c}2004 \\
\text { Islamic Bank of Britain }\end{array}$ & 23 & & 0.07 & $\begin{array}{l}\text { Branches, Islamic } \\
\text { windows }\end{array}$ & $\begin{array}{l}\text { Hub in Europe, } \\
\text { first in Europe } \\
\text { sukuk issuance }\end{array}$ \\
\hline Kazakhstan & $\begin{array}{c}2010 \\
\text { Al-Hilal Bank }\end{array}$ & 2 & - & - & $\begin{array}{l}\text { Conventional and } \\
\text { Islamic }\end{array}$ & $\begin{array}{c}\text { Hub in Central } \\
\text { Asia }\end{array}$ \\
\hline
\end{tabular}


With the data from table 2 , it is possible to allocate following features of Islamic finance and banks in countries with developed Islamic finance system:

- historical background of development and implementation of Islamic financial industry, as it can been seen from analysis most developed countries in this area started implementation of Islamic finance more than 30-40 years ago. It should be noted that, despite the fact that first Islamic bank in the UK was established in 2004, Islamic finance activity started from 1980s;

- the financial market of most developed countries in this issue ether total Sharia based, Iran and Saudi Arabia in our study, as result of that population of these countries is Muslim and all their low and other sectors are totally based on Shariah.

- the financial market of most developed countries in this issue ether really loyal and flexible in using instruments of Islamic finance, Malaysia and UK in our study, that countries where Islamic finance adopted to finance system which has already based in the country. Malaysia established own rules and system of Function of Islamic finance which allowed to increase number of stakeholders, banks, financial institutions, products and tools. As a result $60,6 \%$ of Global sukuk market is based in Malaysia;

- location of the country and number of Muslim population directly impact on development of Islamic finance.

From the analysis bellow and interpretation of results it could be concluded that for Kazakhstan financial and social system the loyal and flexible model of development of Islamic finance is more useful for different reasons. First of all, despite the fact that ethnically most population of our country is Muslim, but really few number of population use all Islam principles in daily life and interest is considered as convenient financial indicator, not as a Riba.

Secondly, there are some difficulties in high requirements of establishing full-fledged Islamic banks and as a result there have been established only 2 banks for period of more than 10 years and 1 of them is totally foreign bank. By using Islamic windows system there would be possible to improve and rise the number of financial institution which could provide Islamic finance tools.

Thirdly, for developing supply of the tools of Islamic finance it is important to improve the financial literacy of population in Islamic finance by demonstrating advantages of the products.
And in this case Malaysian and UK experiences are also useful, because these two countries have the strong business schools in Islamic finance and market.

It is important to notice that Islamic finance is the system that based on development real sector of economic and based on real assets without aby speculative characteristics. In addition, this feature is very necessary for attracting international investment in economics of the country for further development and national prosperity.

\section{Conclusion}

The Islamic financial system is the only system that has shown its stability during the global crisis and is actively developing not only in Muslim but also in other European countries.

International experience of the development of Islamic finance has huge importance for the further development and improvement of Islamic finance in Kazakhstan.

There are number of recommendations that concluded by the authors during study of foreign experience of implementation Islamic finance:

- improvement the ways to the attraction of population's savings in the Islamic banks, by introducing school banking, so that they do not face a liquidity squeeze, and the young generation is introduced to Islamic banking;

- improvement of the legal framework using international experience and amendments to the tax code to avoid double taxation;

- expanding the range of Islamic finance tools offered to consumers;

- to start actively to develop the retail Islamic Finance, as Islamic Finance repairs proposed major corporate sector;

- using Malaysian and British experience of rapid development of Islamic Finance, consider the introduction of Islamic Windows.

For the financial system of Kazakhstan, affected by the crisis, the attraction and development of Islamic Finance is very important and promising.

It is also should be noting that there is the potential role of Islamic Finance in helping to solve a number of state economic problems such as financial support for small and medium-sized businesses, the expansion of the list of services provided by the financial sector, the development of programs of the halal industry, the introduction of new educational programs. 


\section{References}

Antropov V. (2017) Islamic banks in the international financial system. Money and Credit, vol. 7(12), pp. 57-64.

Chartered Institute for Securities \& Investment's (2018) Islamic Finance Qualification, $8^{\text {th }}$ edition. London, p. 242.

CIBAFI (2018) Global Islamic Bankers'survey 2018: evaluating future Impacts, strategic thinking, branding and financial technologies. Bahrain.

Dubai Islamic Bank (2017) Overview of the global islamic finance industry, Global Islamic Finance report. Dubai, p. 39.

Dubai Islamic bank (2017) Overview of the Global Islamic finance industry. Dubai, p.11

EcoIslamicBank (2018) Financial report of EcoIslamicBank by 31.12.2017. Bishkek

F. di Mauro, Pierluigi C., Couderc S., Di Maria A., Ho L., Grewal B.K., Masciantonio S., Ongena S., Zaher S. (2013) Islamic finance in Europe. European central bank, Germany, p. 29-33.

General Council for Islamic Banks and Financial Institutions and The World Bank Group (2017) Kingdom of Bahrain, 56 p.

Global Islamic Finance Report (2018) Published by Edbiz Corporation. London, p. 48.

https://www.telegraph.co.uk/business/2017/10/15/can-uk-make-sukuk-islam-compliant-bond/ - electronic resource

Interview of Head of National Bank of Kyrgyzstan from 28.03.2017 to 24.kz www.24.kz

Islamic financil services board (2018) Islamic financial services industry stability report. Bank Negara Malaysia, p.12, 93.

Issam Tlemsani (2015) Qatar as an Emerging Islamic Finance Hub. Journal of Modern accounting and Auditing, vol. 11, pp. 596-605.

Kuanova L. (2018) Transit economic 3(4), Econometric model of the development of Islamic finance in Kazakhstan. Almaty

Kuanova L., Mukadam P. (2018) Alternative financing of the economy - Islamic finance in Kazakhstan. A paper presented at the the international scientific and practical conference «Innovative and entrepreneurial education in the context of improving the quality of life» (Turan).

Kuanova L., Sagiyeva R. (2018) Islamic finance in Kazakhstan and economic growth: potential and prospects. A paper presented at the the international scientific and practical conference «Innovative and entrepreneurial education in the context of improving the quality of life» (Turan).

Mohamed Sh., Goni A., Hasan Sh. (2018) Islamic fianace development report. Thomson Reuters IFDI.

Official web site of the Bank Negara Malaysia/Central Bank of Malaysia www.bnm.gov

Official web site of the Islamic Financial Services Board www.ifsb.org

Official web-site of National bank of Kyrgyz Republic https://www.nbkr.kg

Official web-site of Qatar Central Bank http://www.qcb.gov.qa/

Salman Syed Ali, Nasim Shah Shirazi, M. Sami Nabi (2013) Role of Islamic Finance in Development of IDB member Countries: A Case Study of Kyrgyz Republic and Tajikistan. Knowledge Review.

Standard\&Poors Global ratings (2018) Islamic finance outlook. Dubai.

Wayne Evans (2017) Islamic finance in the UK. British embassy Bishkek, gov.uk/ukti. 